\title{
Analysis of the Influence of Public Relations and Price Towards Consumer Buying Interest in Make-Up Artist Service (Case Study on Aliefiah Pranedya Make-Up Artist)
}

\author{
Aliefiah Pranedya \\ AP Makeup Artist \\ aliefiahpranedya@ymail.com \\ https://doi.org/10.37715/rmbe.v1i2.2431
}

\begin{abstract}
Make-up artist services is one of the businesses that lately is growing rapidly and has considerable growth potential. Marketing services such as make-up artist, running optimally when supported by structured planning It includes activities in the marketing mix of services that begin from identifying products as consumer needs that will be met, determining prices, promotional activities to be carried out, locations to market products to consumers, assigning people involved in business activities, as well as organizing processes to be used in business activities and also physical evidence. So the purpose of this research researchers want to find out more about public relations and prices can influence consumer buying interest in make-up artist services. This research is a quantitative research with the consumer population of women who have used the services of make-up artists in the city of Surabaya with an infinite number of population using Cosenza \&amp; Davis so that using 385 respondents with the criteria that is prospective consumers AP Make-up Artist female gender with a range of age 15-49 years and residents of Surabaya. The conclusion of this research is public relations factor and price influence on consumer purchasing interest in make-up artist services.
\end{abstract}

Keywords—Make-up Artist, Public Relations, Price, and Purchase Interest.

\section{Introduction}

According to the Health Science Authority (2020), cosmetic products can be defined as any natural or synthetic material or mixture intended for use in various parts of the human body or teeth for the purpose of cleaning, fragrance, enhancing or changing the consumer's appearance to keep it in good condition. The cosmetics industry is a highly profitable, innovative, and fast-paced industry where product innovation is the key to success.

Based on data from the BPS in 2019 the number of residents who are female is 49.77\%, of which Indonesian women have the potential to become the largest users of cosmetics and make-up. The make-up artist business is one of the businesses that is currently growing rapidly and has the potential to grow quite large. There are many reasons that can cause someone to need a make-up artist, such as the desire to look beautiful on special occasions such as proposals, graduations, weddings, and other special events (Wut \& Ng, 2015).

AP Make-up Artist is a start-up business established in 2019 which is engaged in art services, especially in the fields of beauty, make-up. The make-up offered is party make-up, graduation, photoshoot to make-up for weddings. And so far, AP Make-up artists have offered their services through the help of Instagram social media. Currently, consumers choose to look for make-up artists by looking at the make-up portfolios that have been done by makeup artists through social media Instagram (Casaló et al., 2021). According to Casaló et.al. (2021) social media platforms such as Instagram can be used as a place to show the work by expressing its individuality. According to Kotler and Armstrong (2012, p. 432), the promotional mix is a specific mix of various promotional tools that companies use to convey customer value persuasively and build customer relationships. In the early stages of this research, a pre-survey was conducted on 35 respondents to find out what the respondents considered when choosing the services of a make-up artist. Give a graph of the results of the pre-survey. 


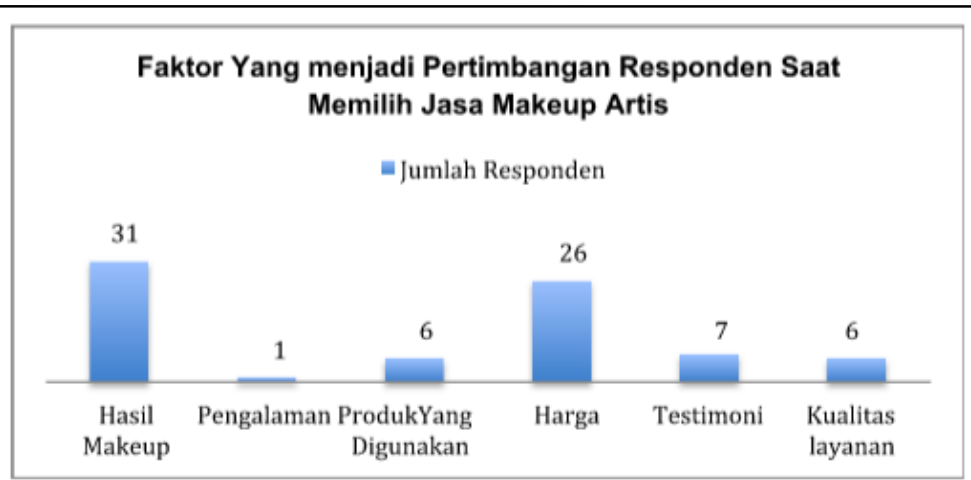

Figure 1.1. Factors That Are Considered by Respondents When Choosing Make-up Artist Services Sources: Company internal data, processed by 2020 researchers.

According to Saragih (2012) public relations (PR) has a role in system development and business is needed starting from the macro level to the micro level. This is supported by research by Fildzah and Mayangsari (2018) that public relations activities become you in indirect promotion. According to research conducted by Jaya and Sriningsih (2018)) prices can have a significant effect on buying interest. Based on the above background, both the results of the pre-survey and the study of literature, the researcher wants to find out more about the influence of public relations and prices on consumer buying interest in make-up artist services by conducting a case study on Aliefiah Pranedya Make-up Artist. The results of this study are expected to provide input for researchers and become a reference for AP Make-up Artists to make improvements to public relations and prices in choosing make-up artist services and are also expected to be a source of reference input for researchers in the future so that they can become a source of reference for future researchers evaluation tool for future researchers.

\section{Literature Review}

\subsection{Penelitian Terdahulu}

The first research according to Maulana and Mulyana (2020) with the research title "Analisis Pengaruh Public Relation dan Sales Promotion terhadap Minat Beli Pada Produk Starbucks di Kota Bogor". The purpose of this study was to determine the effect of each Public relations indicator and Sales Promotion Indicator on Purchase Interest on Starbucks products. The results of this study indicate that the variables of Public relations and Sales Promotion have a positive and significant effect on consumer buying interest.

The second research according to Kusumawati et al. (2014) with the research title "The Influence of 7P's of Marketing Mix on Buying Intention of Music Product in Indonesia". The purpose of this study is to examine every factor that can affect consumer buying interest in music products. The method used using multiple linear regression analysis and data obtained through questionnaires and analyzed using multiple regression analysis. The results show that price has the greatest influence on consumers in buying music products. Price is the main consideration for consumers to buy music products.

The third research according to Tantono (2018) with a study entitled "Pengaruh Promotion Mix Terhadap Minat Beli Konsumen Strap". The purpose of this study was to determine the effect of 6 out of 8 variables from the promotion mix on consumer buying interest in straps. The results of this study are all the promotional mix variables studied have a significantly positive effect on consumer buying interest in straps.

The fourth study according to Tristantin and Suwandi (2013) with the "Pengaruh promotion Mix terhadap minat beli konsumen di Family Fun Karaoke Keluarga". The purpose of the study was to determine the effect of promotion mix on consumer buying interest in Family Fun Karaoke. The results of the analysis show that the variables of advertising, sales promotion and public relations have a positive and significant influence on consumer buying interest.

The fifth study according to Septiani et al. (2016) with the research title "Aktivitas Corporate Social Responsibility (CSR) dan publisitas media: Dampaknya terhadap citra perusahaan dan minat beli (Studi Kasus: konsumen Aqua kelas menengah ke atas di Kota Semarang)". The purpose of the study was to determine whether this research model was accepted or rejected. The results showed that this research model was acceptable. The direct 
effect of CSR on purchase intention and indirect effect through the mediation of corporate image in the research model proved to have a significant effect.

\subsection{Theoretical basis}

The grand theory in this study uses the theory of consumer behavior. Consumer behavior is the behavior displayed by customers in seeking the purchase, use, evaluation and use of products, services and ideas that consumers expect to satisfy their needs (Schiffman \& Kanuk, 2018) According to Kotller \& Keller (2016, p. 450) describes consumer behavior as the study of how individuals, groups and organizations choose, buy, use, and how goods, services, ideas, or experiences can satisfy their needs and wants. Kotler and Armstrong (2012) state that a special combination of promotional tools that companies use to persuasively communicate customer value and can build customer relationships, namely Advertising or Advertising, Sales Promotion or Sales Promotion, Personal Selling or Personal Selling, Public Relations or Public Relations, Direct Marketing or Direct Marketing. According to Kotler \& Keller (2008, as cited in Syaiful \& Sari, 2017, p. 98), there are several factors that influence consumer behavior, namely: cultural, social, personal, and psychological factors. Purchase intention or buying interest has a relationship with consumer purchasing decision theory, because it is one of the final processes in consumers in making purchasing decisions. Purchase intention is something that arises after receiving exposure to the product he sees, where there will be an interest in trying the product until finally a desire arises to buy it in order to have it (Kotler \& Keller, 2008).

\subsubsection{Public relations}

According to Kotler \& Armstrong (2008, as cited in Tristantin \& Suwandi, 2013) public relations is a good relationship with the various communities of a company by obtaining the desired publicity, building a good corporate image, and dealing with or dealing with rumors, stories, and unexpected events. pleasant. Public relations criteria according to Kotler \& Armstrong (2008, as cited in Tristantin \& Suwandi, 2013) can be divided into three things, namely:

1. The news that spreads about the company is good,

2. Unique corporate identity, different from others,

3. Community service activities.

The public relations indicators:

1. Publication: namely the delivery of information to the public so that consumers know information through a media,

2. Event: a series of activities/events held by a company to get the attention of consumers on a product being sold,

3. Sponsorship: a way of promoting a company by sponsoring certain events to promote and improve the image of the company's products,

4. Reporting: namely the delivery of information about a product by publishing news reports so that consumers feel interested in a product.

\subsubsection{Price}

According to Ananingsih et al. (2018) Price is an element that is different from other elements in the marketing mix, other elements in the marketing mix such as product, location, and promotion are more expenditure, so price is an element that is generating or getting income, so that Price is the value of an item expressed in money. There are several indicators in the price, namely:

1. Price affordability. Affordable prices are consumer expectations before making a purchase, consumers will look for products whose prices they can reach.

2. Price competitiveness. The company determines the selling price of a product by considering the price of the product sold by its competitors so that its products can compete in the market.

3. Price compatibility with product/service quality. There are certain products that consumers usually do not mind if they have to buy at high prices as long as they are accompanied by good quality.

4. Price compatibility with product/service benefits. Consumers sometimes ignore the price of a product but are more concerned with the benefits of the product. 


\subsubsection{Buying interest}

According to Ariescy et al. (2019) Purchase interest is part of behavior in consuming. Jaya and Sriningsih (2018) state that buying interest is part of consumer behavior that aims to determine the process of developing decisions in purchasing an item or service where individuals are directly involved in obtaining and using the goods or services offered. According to Jaya and Sriningsih (2018) mentions indicators in buying interest, namely:

1. Transactional interest is a person's tendency to buy a product.

2. Referential interest is a person's tendency to refer products to others.

3. Preferential interest is the feeling of someone who wants to have a product with the main preference. These preferences will be replaced if something happens to the preference product.

4. Explorative interest is a person's tendency to search for information related to the product of interest to support the positive characteristics of the product.

\section{Research Methods}

\subsection{Analysis Model}

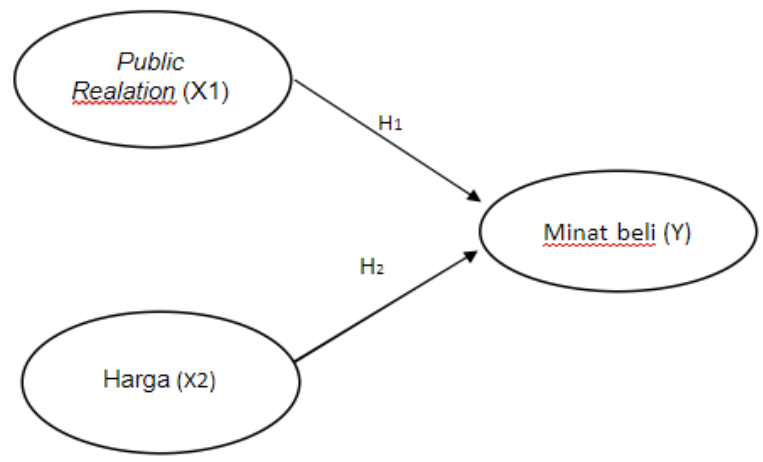

Figure 3.1. Model Analisis

Sources : data processed by researchers

\subsection{Research Hypothesis}

Based on the explanation above, the hypothesis of this research is as follows:

- $\mathrm{H}_{1}$ : Public relations has a significant effect on consumer buying interest in the services AP Make-up Artist.

- $\mathrm{H}_{2}$ : Price has a significant effect on consumer buying interest in AP Make-up Artist services

\subsection{Research Approach}

In this research, the type of research used is quantitative research. In this study, the population used is female consumers who have used the services of a make-up artist in the city of Surabaya with an infinite number of populations. This study takes samples that have the characteristics of women, with an age range of 15-49 years and residents of the city of Surabaya according to the unlimited number of AP Make-up Artist consumers. In order to determine the number of samples in this study with an infinite population, the formula used (Duane \& Cosenza, 1996). So in this study using 385 respondents with the criteria that prospective consumers of AP Make-up Artist are female with an age range of 15-49 years and residents of the city of Surabaya. In this study, the type of data used is primary data and secondary data. Primary data is generated by collecting directly from the object of research, namely by distributing questionnaires to selected respondents (Sugiyono, 2017). Secondary data in the form of written or unwritten information obtained from journals, books, internet related to this research (Sugiyono, 2017). Collecting data in this study by distributing online questionnaires that were distributed to female consumers who had used the services of a make-up artist. Dissemination of questionnaires by giving written statements to respondents to be answered. The questionnaire contains several alternative answers in the form of a Likert scale.

$\begin{array}{lll}\text { SS } & =\text { Strongly Agree } & \text { value } 5 \\ \text { S } & =\text { Agree } & \text { value } 4 \\ \text { CS } & =\text { Simply Agree } & \text { value } 3 \\ \text { TS } & =\text { Disagree } & \text { value } 2 \\ \text { STS } & =\text { Strongly Disagree } & \text { value } 1\end{array}$




\subsection{Analytical Methods and Hypothesis Testing}

\subsubsection{Analytical Methods and Hypothesis Testing}

If an item is declared valid, there is a significant correlation with the total score, this can prove that there is support for the item in revealing something that will be revealed. This study uses a Pearson correlation measuring instrument. The criteria used are if the significant value is $<0.05$, then the data can be said to be valid (Priyatno, 2014, p. 51). The criteria used in the reliability test is if the Cronbach alpha value $>0.6$ then the data can be said to be reliable.

\subsubsection{Classic assumption test}

a. Residual Normality Test

The normality test is used to test the residual value resulting from the regression whether it is normally distributed or not. The criteria used by the residual normality test is if the significance value (Sig) $>0.05$, it can be stated that the residual value is normally distributed and can be said to be good (Priyatno, 2014, p. 90).

b. Multicollinearity Test

According to Priyatno (2014, p. 90) the multicollinearity test is used to determine whether the independent variables in the regression model have a perfect or near perfect linear relationship. The criterion used is if the VIF value is < 10, it can indicate that there is no multicollinearity or the independent variable in the regression model does not have a linear relationship.

c. Heteroscedasticity Test

The heteroscedasticity test is the residual variance that is not the same in all observations in the regression model. In this study using the Spearman's rho correlation method. Spearman's rho correlation method is to correlate the independent variables with their residuals. The criterion used is if the value ( $\mathrm{Sig})>0.05$, it can be stated that there is no heteroscedasticity (Priyatno (2014, p. 108).

d. Linearity Test

Linearity test can be used to determine the linearity of a data, whether two variables have a linear relationship (straight line) or not. The criteria used are test for linearity on SPSS by using a level (Sig) of 0.05. Two variables can be stated to have a linear relationship if the significance value is $<0.05$ (Priyatno, 2014, p. 79).

\subsubsection{Multiple Linear Regression Analysis}

In this study, the multiple linear regression equation with three independent variables is as follows:

Description:

$$
Y=\alpha+\beta_{1} X_{1}+\beta_{2} X_{2}+e
$$

Y

$\alpha$

$\beta_{1}, \beta_{2}$,

$\mathrm{X}_{1}$

$\mathrm{X}_{2}$

e

\subsubsection{F test}

$=$ Buying interest

$=$ Constant

$=$ Regression Coefficient

$=$ Public relations

$=$ Price

$=$ Residual

The $\mathrm{F}$ test can show whether all the independent variables in the research model have a joint influence on the dependent variable. The criterion used is if the significance value is $<0.05$, it can be concluded that the independent variable (X) simultaneously affects the dependent variable (Y) (Priyatno, 2014, p. 157).

\subsection{5. $\quad$ t test}

According to Priyanto (2014, p. 157) the t test can be used to find out partially the independent variables have a significant effect on the dependent variable. The criteria used are if the significance value is $<0.05$, the independent variable partially has a significant effect on the dependent variable (Priyatno, 2014, p. 157).

\subsubsection{Correlation Coefficient $(R)$ and Coefficient of Determination $\left(R^{2}\right)$}

The correlation coefficient is a value that can show the close relationship between variables. The value of the correlation coefficient ranges from -1 to 1 with the exception of $\mathrm{R}=0$. The criterion used is that the closer the value is to 1 , the stronger the relationship is and vice versa, the closer the value is to 0 , the weaker the relationship 
between variables. The coefficient of determination $\left(\mathrm{R}^{2}\right)$ can express the proportion of diversity in the dependent variable that can be explained by the independent variable. The value of $R^{2}$ ranges $0-1$. The criteria used is if the value of $\mathrm{R}^{2}$ approaching 0 , it can indicate that the influence of the independent variables on the dependent variable is getting weaker and vice versa if the figure close to 1 independent variables affect the dependent variable getting stronger (Priyanto, 2014, p. 155).

\section{Result and Discussion}

\subsection{Description of Research Results}

AP Make-up Artist is a start-up business established in 2019 which is engaged in art services, especially in the fields of beauty, make-up. The make-up offered is party make-up, graduation, photoshoot to make-up for weddings. AP Make-up Artist offers its services through the help of social media Instagram. All make-up results or portfolio results owned by AP Make-up artists have been uploaded on Instagram @apranedyamake-up social media. So far, many AP Make-up Artist customers have ordered make-up services because they have seen the portfolio results from AP Make-up Artists.

\subsubsection{Characteristics of Respondents}

The majority of respondents in this survey are students or college students as many as 140 respondents. The number of student respondents or students reached $36.3 \%$ of the total respondents based on the respondent's occupation category. Furthermore, respondents with jobs as employees were 114 people (29.7\%). Then respondents with jobs as entrepreneurs as many as 110 people $(28.6 \%)$ and respondents with other jobs as many as 21 people $(5.4 \%)$.

Table 4.1. Profile of Respondents by Age.

\begin{tabular}{|l|c|c|}
\hline \multicolumn{1}{|c|}{ Age } & Amount & Percentage (\%) \\
\hline $\mathbf{1 5}$ - 25 years & 223 & $57.9 \%$ \\
\hline $\mathbf{2 6}$ - 35 years old & 118 & $30.6 \%$ \\
\hline $\mathbf{3 6}$ - 45 years & 35 & $9.1 \%$ \\
\hline $\mathbf{4 6}$ - 49 years old & 9 & $2.4 \%$ \\
\hline Total & 385 & $100 \%$ \\
\hline
\end{tabular}

\subsubsection{Variabel Public Relations $\left(X_{1}\right)$}

Table 4.2. Average Respondents Answers Public Relations Variables

\begin{tabular}{|c|c|c|c|c|c|c|c|c|}
\hline \multirow[t]{2}{*}{ Pernyataan } & \multicolumn{5}{|c|}{$\begin{array}{l}\text { Frekuensi dan } \\
\text { persentase jawaban dari } \\
\text { responden }\end{array}$} & \multirow[t]{2}{*}{ Mean } & \multirow[t]{2}{*}{$\begin{array}{l}\text { Std. } \\
\text { dev }\end{array}$} & \multirow[t]{2}{*}{ Kategori } \\
\hline & Sts & Ts & Cs & $\mathrm{s}$ & Ss & & & \\
\hline $\begin{array}{l}\left(X_{1,1}\right) \\
\text { mengetahui Saya } \\
\text { mengenai informasi } \\
\text { make-up artist dari } \\
\text { berbagai } \\
\text { sosial. }\end{array}$ & 0 & 2 & 98 & $\begin{array}{c}20 \\
0\end{array}$ & 85 & 3,96 & 0,704 & CS \\
\hline $\begin{array}{l}\left(X_{1,2}\right) \text { Event } \text { beauty } \\
\text { class yang yang } \\
\text { diadakan oleh make- } \\
\text { up artist menarik } \\
\text { perhatian saya. }\end{array}$ & 0 & 4 & $\begin{array}{c}16 \\
3\end{array}$ & $\begin{array}{c}18 \\
2\end{array}$ & 36 & 3,65 & 0,661 & CS \\
\hline 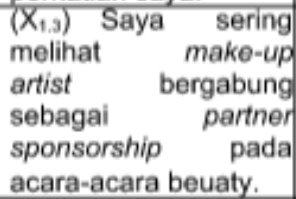 & 0 & 0 & 32 & $\begin{array}{c}23 \\
2\end{array}$ & $\begin{array}{c}12 \\
1\end{array}$ & 4,23 & 0,587 & $S$ \\
\hline $\begin{array}{lr}\left(X_{1,4}\right) \text { Pemberitaan } \\
\text { yang positif mengenai } \\
\text { make-up artist } \\
\text { menarik perhatian } \\
\text { saya untuk ingin } \\
\text { menggunakan jasa } \\
\text { make-up artist. }\end{array}$ & 0 & 1 & 87 & $\begin{array}{c}23 \\
6\end{array}$ & 61 & 3,93 & 0,625 & CS \\
\hline Nilai Total & $\begin{array}{c}\text { Publ } \\
c\end{array}$ & rel & ions & & & 3,94 & 0,644 & CS \\
\hline
\end{tabular}

Source: SPSS data processed by researchers, 2021 
The statement (X1.1) has the highest standard deviation value, which is 0.704 when compared to other statements, so it can be said that a high deviation value identifies that the data has deviations between answers that are far compared to other statements.

\subsubsection{Price Variable $\left(X_{2}\right)$}

Table 4.3. Average Respondents Answer Price Variable.

\begin{tabular}{|c|c|c|c|c|c|c|c|c|}
\hline \multirow[t]{2}{*}{ Pernyataan } & \multicolumn{5}{|c|}{$\begin{array}{c}\text { Frekuensi dan } \\
\text { persentase jawaban dari } \\
\text { responden }\end{array}$} & \multirow[t]{2}{*}{ Mean } & \multirow[t]{2}{*}{$\begin{array}{l}\text { Std. } \\
\text { dev }\end{array}$} & \multirow[t]{2}{*}{ Kategori } \\
\hline & Sts & Ts & Cs & $\mathbf{S}$ & Ss & & & \\
\hline $\begin{array}{l}\left(\mathrm{X}_{2.1}\right) \text { Menurut saya, harga } \\
\text { make-up artist terjangkau. }\end{array}$ & 1 & 13 & 96 & $\begin{array}{c}22 \\
1\end{array}$ & 54 & 3,82 & 0,718 & CS \\
\hline $\begin{array}{l}\left(\mathrm{X}_{2.2}\right) \text { Menurut saya, } \\
\text { make-up artist hargas bersaing } \\
\text { antar satu dengan yang } \\
\text { lainnya. }\end{array}$ & 2 & 44 & $\begin{array}{c}17 \\
9\end{array}$ & $\begin{array}{c}11 \\
4\end{array}$ & 46 & 3,41 & 0,862 & CS \\
\hline $\begin{array}{l}\left(\mathrm{X}_{2.3)} \text { Menurut saya, harga }\right. \\
\text { make-up artist harus sesuai } \\
\text { dengan kualitas produk yang } \\
\text { dipakai. }\end{array}$ & 0 & 2 & 25 & $\begin{array}{c}13 \\
6\end{array}$ & $\begin{array}{c}22 \\
2\end{array}$ & 4,50 & 0,642 & $S$ \\
\hline $\begin{array}{l}\left(X_{2.4}\right) \text { Menurut saya, harga } \\
\text { make-up artist sesuai dengan } \\
\text { manfaat yang diterima. }\end{array}$ & 0 & 1 & 32 & $\begin{array}{c}11 \\
9\end{array}$ & $\begin{array}{c}23 \\
3\end{array}$ & 4,52 & 0,658 & $S$ \\
\hline $\begin{array}{l}\text { Nilai } \\
\text { Total }\end{array}$ & Har & & & & & 4,06 & 0,72 & $\mathrm{~S}$ \\
\hline
\end{tabular}

Source: SPSS data processed by researchers, 2021.

The statement (X2.2) has the highest standard deviation value, which is 0.862 when compared to other statements, so it can be said that a high deviation value identifies that the data has deviations between answers that are far compared to other statements.

\subsubsection{Price Variable $\left(X_{2}\right)$}

Table 4.4. Average Respondents Answer Price Variable

\begin{tabular}{|c|c|c|c|c|c|c|c|c|}
\hline \multirow[t]{2}{*}{ Pernyataan } & \multicolumn{5}{|c|}{$\begin{array}{l}\text { Frekuensi dan persentase } \\
\text { jawaban dari responden }\end{array}$} & \multirow[t]{2}{*}{ Mean } & \multirow[t]{2}{*}{$\begin{array}{l}\text { Std. } \\
\text { dev }\end{array}$} & \multirow[t]{2}{*}{ Kategor } \\
\hline & Sts & Ts & Cs & $\mathrm{s}$ & Ss & & & \\
\hline $\begin{array}{l}\left(Y_{11}\right) \text { Saya cenderung } \\
\text { lebih suka menggunakan } \\
\text { jasa make-up artist. }\end{array}$ & 0 & 6 & 117 & 200 & 62 & 3,83 & 0,706 & CS \\
\hline $\begin{array}{lr}\left(\gamma_{12}\right) \text { Saya akan } \\
\text { mereferensikan jasa } \\
\text { make-up artist } & \text { kepada } \\
\text { orang lain. } & \end{array}$ & 0 & 0 & 36 & 207 & 142 & 4,28 & 0,623 & S \\
\hline $\begin{array}{l}\left(\mathrm{Y}_{1,3}\right) \text { Saya akan memilih } \\
\text { jasa make-up artist yang } \\
\text { memiliki jam terbang tinggi } \\
\text { dibanding yang lainnya. }\end{array}$ & 0 & 4 & 107 & 227 & 47 & 3,82 & 0,641 & CS \\
\hline $\begin{array}{l}\left(Y_{1,4} \text { Saya mencari }\right. \\
\text { informasi terlebih dahulu } \\
\text { tentang perusahaan jasa } \\
\text { make-up artist sebelum } \\
\text { saya memilihnya. }\end{array}$ & 0 & 0 & 36 & 245 & 104 & 4,18 & 0,577 & $\mathrm{~S}$ \\
\hline Mean Tote & & & & & & 4,02 & 0,636 & $\mathrm{~S}$ \\
\hline
\end{tabular}

Sumber: Data spss diolah oleh peneliti, 2021.

The statement (Y1.1) has the highest standard deviation value, which is 0.706 when compared to other statements, so it can be said that a high deviation value identifies that the data has deviations between answers that are far compared to other statements. 


\section{2. $\quad$ Research result}

\subsubsection{Validity test}

Table 4.5. Validity Test Results of All Variables.

\begin{tabular}{|c|l|l|l|l|}
\hline \multirow{4}{*}{ Variabel } & Indikator & \multicolumn{3}{|c|}{ Validitas } \\
\cline { 2 - 5 } & $\begin{array}{c}\text { Pearson } \\
\text { Correlation }\end{array}$ & $\begin{array}{c}\text { Sig. } \\
\text { (2-tailed) }\end{array}$ & Kesimpulan \\
\hline \multirow{4}{*}{$\begin{array}{c}\mathbf{X}_{1} \\
\text { (Public } \\
\text { relations) }\end{array}$} & $\mathbf{X}_{1.1}$ & 0,765 & 0,000 & Valid \\
\cline { 2 - 5 } & $\mathbf{X}_{1.2}$ & 0,740 & 0,000 & Valid \\
\cline { 2 - 5 } & $\mathbf{X}_{1.3}$ & 0,516 & 0,000 & Valid \\
\cline { 2 - 5 } & $\mathbf{X}_{1.4}$ & 0,718 & 0,000 & Valid \\
\hline \multirow{4}{*}{$\begin{array}{c}\mathbf{X}_{2} \\
\text { (Harga) }\end{array}$} & $\mathbf{X}_{2.1}$ & 0,718 & 0,000 & Valid \\
\cline { 2 - 5 } & $\mathbf{X}_{2.2}$ & 0,643 & 0,000 & Valid \\
\cline { 2 - 5 } & $\mathbf{X}_{2.3}$ & 0,703 & 0,000 & Valid \\
\cline { 2 - 5 } & $\mathbf{X}_{2.4}$ & 0,746 & 0,000 & Valid \\
\hline \multirow{4}{*}{\begin{tabular}{|}
$\mathbf{Y}_{1}$ \\
(Minat Beli)
\end{tabular}} & $\mathbf{Y}_{1.1}$ & 0,755 & 0,000 & Valid \\
\cline { 2 - 5 } & $\mathbf{Y}_{1.2}$ & 0,685 & 0,000 & Valid \\
\cline { 2 - 5 } & $\mathbf{Y}_{1.3}$ & 0,705 & 0,000 & Valid \\
\cline { 2 - 5 } & $\mathbf{Y}_{1.4}$ & 0,626 & 0,000 & Valid \\
\hline
\end{tabular}

Source: SPSS data processed by researchers, 2021.

Table 4.5. above explains that all indicators in the questionnaire (public relations variable (X1), price variable (X2), and buying interest variable (Y)) have a significant value of $0.000<0.05$. So this shows that all indicators in this study are valid because the value of Sig $<0.05$ and can be used to measure each variable in this research.

\subsubsection{Reliability Test}

Tabel 4.6. Hasil Uji Reliabilitas Semua Variabel.

\begin{tabular}{|c|c|c|c|}
\hline Variable & Indicator & Cronbach Alpha & Conclusion \\
\hline \multirow{4}{*}{$\begin{array}{c}\mathrm{X}_{1} \\
\text { (Public relations) }\end{array}$} & X1.1 & \multirow[t]{4}{*}{0,631} & Reliabel \\
\hline & $\mathrm{X1.2}$ & & Reliabel \\
\hline & $\mathbf{X 1 . 3}$ & & Reliabel \\
\hline & X1.4 & & Reliabel \\
\hline \multirow{4}{*}{$\begin{array}{c}\mathbf{X}_{2} \\
\text { (Price) }\end{array}$} & X3.1 & \multirow[t]{4}{*}{0,641} & Reliabel \\
\hline & $\mathbf{X 3 . 2}$ & & Reliabel \\
\hline & $\mathrm{X3.3}$ & & Reliabel \\
\hline & X3.4 & & Reliabel \\
\hline \multirow{4}{*}{$\begin{array}{c}\mathrm{Y}_{1} \\
\text { (Interest to Buy) }\end{array}$} & Y1.1 & \multirow[t]{4}{*}{0,642} & Reliabel \\
\hline & Y1.2 & & Reliabel \\
\hline & Y1.3 & & Reliabel \\
\hline & Y1.4 & & Reliabel \\
\hline
\end{tabular}

Source: SPSS data processed by researchers, 2021.

Based on Table 4.6. promotion variable $\left(\mathrm{X}_{1}\right)$, service quality variable $\left(\mathrm{X}_{2}\right)$, price variable $\left(\mathrm{X}_{3}\right)$ and buying interest variable $(\mathrm{Y})$ each have a Cronbach's Alpha value $>0.6$ so it can be concluded that all indicators used to measure the variable $\mathrm{f}$ on this research is reliable. So the questionnaire can be said to be reliable.

\subsection{Multiple Linear Regression Analysis}

Table 4.7. Multiple Linear Regression Test Results

\begin{tabular}{|c|c|c|}
\hline & \multicolumn{2}{|c|}{ Unstandardized Coefficients } \\
\hline & B & Std.eror \\
\hline Constantan & 5.402 & 0,803 \\
\hline $\mathrm{X}_{1}$ (Public relations) & 0,247 & 0,042 \\
\hline $\mathrm{X}_{2}$ (Price) & 0,419 & 0,038 \\
\hline
\end{tabular}

Source: SPSS data processed by researchers, 2021.

Based on Table 4.7. it can be seen that the results of multiple linear regression, the regression model is obtained as follows:

$$
\mathrm{Y}=5.402+0,247 \mathrm{X}_{1}+0,419 \mathrm{X}_{2}
$$

The regression equation can be explained as follows: 
1. The regression coefficient has a value of 5.402, this shows that if the independent variables, namely $\mathrm{X}_{1}$, $\mathrm{X}_{2}$, are equal to 0 or there is no change, the amount of buying interest is 5,402 units.

2. The regression coefficient public relations $\left(X_{1}\right)$ of 0.247 can be said that if the indicators of public relations AP Make-up Artist upgraded one unit points then can be interpreted will boost buying interest on the level of public relations offered by AP Make-up Artist, then variable interest in purchasing will increase by 0.247 units assuming the price variable is considered constant. If the indicator variable PR $\left(\mathrm{X}_{1}\right)$ decreased one unit points then can be interpreted will reduce buying interest on the level of public relations at the AP Make-up Artist, then variable interest in buying will decrease of 0.247 units assuming the price variables held constant.

3. The price frequency coefficient $\left(\mathrm{X}_{2}\right)$ has a value of 0.419. If the AP Make-up Artist price indicator is increased by one unit point, it means that it will increase buying interest at the price offered by AP Makeup Artist. The buying interest variable will increase by 0.419 units with the assumption that the public relations variable is considered constant. If the price variable indicator $\left(\mathrm{X}_{2}\right)$ has decreased by one unit point, it means that it will reduce buying interest in the price level offered by AP Make-up Artist. The buying interest variable will decrease by 0.419 units with the assumption that the public relations variable is considered constant.

\subsection{Hypothesis Test Results}

\subsubsection{F Test Results}

Table 4.8. Multiple Linear Regression Test Results

\begin{tabular}{|l|c|c|}
\hline \multicolumn{2}{|c|}{ ANOVA } \\
\hline \multicolumn{1}{|c|}{ Model } & F & Sig \\
\hline 1. Regression & 98.476 & 0,000 \\
\hline Residual & & \\
\hline Total & & \\
\hline
\end{tabular}

Source: SPSS data processed by researchers, 2021.

Table 4.8. shows the results of the $F$ test with a significance level of $0.000<0.05$ resulting in a calculated $\mathrm{F}$ of 98.476. These results indicate that the public relations variable $\left(\mathrm{X}_{1}\right)$ and the price variable $\left(\mathrm{X}_{2}\right)$ together have a significant effect on buying interest in make-up artist services (Y).

\subsection{2. $\quad$ t test results}

Table 4.9. Multiple Linear Regression Test Results

\begin{tabular}{|c|c|c|c|}
\hline Variable & Coefficient & Significant & Conclusion \\
\hline X1 ( Public relations) & 5.807 & 0.000 & $\mathrm{H}_{1}$ accepted \\
\hline X2 (Price) & 11.162 & 0.000 & $\mathrm{H}_{2}$ accepted \\
\hline
\end{tabular}

Source: SPSS data processed by researchers, 2021.

Based on Table 4.9. public relations variables $\left(\mathrm{X}_{1}\right)$ have a significance value of $0.000>0.05$, which show that $\mathrm{H}_{1}$ and $\mathrm{H}_{2}$ is received. In this study, public relations has a significant effect on consumer buying interest in choosing make-up artist services and price significantly affects consumer buying interest in choosing make-up artist services.

\subsubsection{Coefficient of Determination $\left(R^{2}\right)$ and Correlation Coefficient $(R)$}

Table 4.10. Coefficient of Determination $\left(\mathrm{R}^{2}\right)$ and Coefficient of Correlation (R).

\begin{tabular}{|c|c|c|}
\hline Koefisien Korelasi $(\mathrm{R})$ & $\begin{array}{c}\text { Koefisien Determinasi } \\
\left(\mathrm{R}^{2}\right)\end{array}$ & $\begin{array}{c}\text { Adjusted } \\
\mathbf{R}^{2}\end{array}$ \\
\hline 0,583 & 0,340 & 0,337 \\
\hline
\end{tabular}

Source: SPSS data processed by researchers, 2021.

Table 4.10 shows that the correlation coefficient $(\mathrm{R})$ is 0.583 , which means that there is a fairly strong relationship between Public Relations ( $\left.\mathrm{X}_{1}\right)$, Price $\left(\mathrm{X}_{2}\right)$ and Purchase Interest (Y). Value coefficient of determination indicates that the variable Public relations $\left(\mathrm{X}_{1}\right)$ and Price $\left(\mathrm{X}_{2}\right)$ is able to contribute to changes in variable interest Buy (Y) in choosing the services of make-up artist for 34\%, while the remaining 66\% is explained 
by other variables outside of this research . According to research conducted by Jaya and Sriningsih (2018), it is stated that buying interest can be influenced by lifestyle variables. Halfinif is also supported by the results of research by Ariescy et al. (2019) which suggests that buying interest in a product or service can be influenced by advertising variables. So it can be concluded that $66 \%$ of the variables that are likely to be able to contribute to changes that occur in the consumer buying interest variable in choosing the services of a make-up artist are lifestyle variables, advertisements and so on.

\subsection{Classic assumption test}

\subsubsection{Normality test}

Table 4.11. Normality Test Results with Kolmogorov-Smirnov test

\begin{tabular}{|c|c|}
\hline Model & Unstandardized Residual \\
\hline $\mathbf{N}$ & 385 \\
\hline Test Statistic & 0,27 \\
\hline Asymp. Sig. (2-tailed) & 0,200 \\
\hline
\end{tabular}

Source: SPSS data processed by researchers, 2021.

Based on the table above, the Asymp value. the significance is $0.200>0.05$, so it can be said that the residual value is normally distributed or in other words the assumption of normality is met.

\subsubsection{Multicollinearity Test}

Table 4.12. Multicollinearity Test Results

\begin{tabular}{|c|c|c|}
\hline Variabel & VlF & Kesimpulan \\
\hline $\begin{array}{c}\mathrm{X}_{1} \\
\text { (Public relations) }\end{array}$ & 1,052 & Tidak terjadi multikolinieritas \\
\hline $\begin{array}{c}\mathrm{X}_{2} \\
\text { (Harga) }\end{array}$ & 1,052 & Tidak terjadi multikolinieritas \\
\hline
\end{tabular}

Source: SPSS data processed by researchers, 2021.

Based on table 4.12 the statistical value shows that each independent variable $\mathrm{X}_{1}$ and $\mathrm{X}_{2}$ all have a VIF value of $1.052<10$ so it can be concluded that there is no multicollinearity or there is no close relationship between variables $(\mathrm{X})$.

\subsubsection{Heteroscedasticity Test}

Table 4.13. Heteroscedasticity Test Results

\begin{tabular}{|c|c|c|}
\hline Variabel & Sig. (2-tailed) & Kesimpulan \\
\hline $\begin{array}{c}\mathrm{X}_{1} \\
\text { (Public relations) }\end{array}$ & 0,681 & Homokesdatisitas \\
\hline $\begin{array}{c}\mathrm{X}_{2} \\
\text { (Harga) }\end{array}$ & 0,609 & Homokesdatisitas \\
\hline
\end{tabular}

Source: SPSS data processed by researchers, 2021.

Based on Table 4.13. the public relations variable $\left(\mathrm{X}_{1}\right)$ has a significance value (Sig. 2-tailed) of 0.681 and the price variable $\left(\mathrm{X}_{2}\right)$ has a significance (Sig. 2-tailed) of 0.609. both independent variables have a significance value of Sig. 2-tailed $>0.05$ so it can be concluded that the two independent variables do not have heteroscedasticity symptoms and it can be said that the assumption is fulfilled.

\subsubsection{Linearity Test}

Table 4.14. Public Relations Linearity Test.

\begin{tabular}{|c|c|c|c|c|c|c|c|}
\hline \multicolumn{8}{|c|}{ ANOVA Table } \\
\hline & & & $\begin{array}{l}\text { Sum of } \\
\text { Squares }\end{array}$ & df & Mean Square & $\mathrm{F}$ & Sig. \\
\hline \multirow{5}{*}{$\begin{array}{l}\text { MINAT_BELI* } \\
\text { PUBLIC_RELATIO } \\
\mathrm{N}\end{array}$} & \multirow[t]{3}{*}{ Between Groups } & (Combined) & 194.535 & 10 & 19.453 & 7.186 & .000 \\
\hline & & Linearity & 150.862 & 1 & 150.862 & 55.725 & .000 \\
\hline & & $\begin{array}{l}\text { Deviation from } \\
\text { Linearity }\end{array}$ & 43.673 & 9 & 4.853 & 1.792 & .068 \\
\hline & \multicolumn{2}{|l|}{ Within Groups } & 1012.515 & 374 & 2.707 & & \\
\hline & \multicolumn{2}{|l|}{ Total } & 1207.049 & 384 & & & \\
\hline
\end{tabular}

Source: SPSS data processed by researchers, 2021.

Based on Table 4.14. it can be seen that the significance value of Linearity between the buying interest variable and the public relations variable $<0.05$ is 0.000 . So it can be concluded that buying interest has a linear relationship with public relations. 
Table 4.15. Price Linearity Test

\begin{tabular}{|c|c|c|c|c|c|c|c|}
\hline \multicolumn{8}{|c|}{ ANOVA Table } \\
\hline & & & $\begin{array}{l}\text { Sum of } \\
\text { Squares }\end{array}$ & df & Mean Square & $\mathrm{F}$ & Sig. \\
\hline \multirow{5}{*}{$\begin{array}{l}\text { MINAT_BELI * } \\
\text { HARGA }\end{array}$} & \multirow[t]{3}{*}{ Between Groups } & (Combined) & 362.584 & 10 & 36.258 & 16.058 & .000 \\
\hline & & Linearity & 340.326 & 1 & 340.326 & 150.725 & .000 \\
\hline & & $\begin{array}{l}\text { Deviation from } \\
\text { Linearity }\end{array}$ & 22.258 & 9 & 2.473 & 1.095 & .365 \\
\hline & \multicolumn{2}{|l|}{ Within Groups } & 844.465 & 374 & 2.258 & & \\
\hline & \multicolumn{2}{|l|}{ Total } & 1207.049 & 384 & & & \\
\hline
\end{tabular}

Source: SPSS data processed by researchers, 2021.

Table 4.15 shows the significant value of Linearity between the buying interest variable and the price variable $<0.05$, which is 0.000 . So it can be concluded that buying interest has a linear relationship with price.

\section{Conclusions and Practical Implication}

\subsection{Conclusion}

Based on the results of the research and discussion that have been stated previously, it can be concluded that. Public relations has a positive and significant influence on consumer buying interest in choosing the services of a make-up artist. So that the first hypothesis Public relations has a significant influence on consumer buying interest in make-up artist services is accepted. Increased public relations variables can increase consumer buying interest in using the services of a make-up artist. Price has a positive and significant influence on consumer buying interest in the services of a make-up artist. So the third hypothesis is that price has a significant effect on consumer buying interest in make-up artist services. An increase in the price variable can increase consumer buying interest in using the services of a make-up artist.

\subsection{Practical Implication}

Table 5.1. Public Relations

\begin{tabular}{|c|c|c|c|}
\hline No & Indicator & Before Research & After Research \\
\hline 1 & Publication & $\begin{array}{l}\text { Customers know } \\
\text { regarding make-up } \\
\text { information } \\
\text { up artist from various } \\
\text { social media. }\end{array}$ & $\begin{array}{l}\text { AP Make-up Artist will maintain an evaluation of their social media, by } \\
\text { being more active in posting activities }\end{array}$ \\
\hline 2 & Events & $\begin{array}{l}\text { Beauty class events that } \\
\text { held by make-to-do a } \\
\text { beauty up artist event } \\
\text { attracts attention. }\end{array}$ & $\begin{array}{l}\text { AP Make-up Artist will take classes in collaboration with make-up artists } \\
\text { who are in great demand and carry interesting and currently happening } \\
\text { themes. }\end{array}$ \\
\hline 3 & Sponsorship & $\begin{array}{l}\text { Often see make-up } \\
\text { artist joined as } \\
\text { sponsorship partner at } \\
\text { beauty events. }\end{array}$ & $\begin{array}{l}\text { AP Make-up Artist will participate in various collaborations with various } \\
\text { vendors to increase their portfolio and introduce make-up services to a } \\
\text { wider range of consumers, such as working with wedding organizer } \\
\text { vendors, clothing rentals, modeling agencies and so on. }\end{array}$ \\
\hline 4 & news & $\begin{array}{l}\text { Positive news } \\
\text { about make-up artist } \\
\text { caught my attention } \\
\text { to want to use the services } \\
\text { of a make-up artist. }\end{array}$ & $\begin{array}{l}\text { AP Make-up Artist will evaluate and collaborate with influencers in } \\
\text { collaborating so that make-up services are more widely known by the } \\
\text { public }\end{array}$ \\
\hline
\end{tabular}

Table 5.2. Managerial Implications of Price

\begin{tabular}{|c|c|c|c|}
\hline No & Indicator & Before Research & After Research \\
\hline 1 & $\begin{array}{l}\text { Price } \\
\text { affordability }\end{array}$ & $\begin{array}{l}\text { Customers feel that the } \\
\text { prices of make-up artists } \\
\text { are affordable. }\end{array}$ & $\begin{array}{l}\text { AP Make-up Artist will evaluate and evaluate the price of the make-up } \\
\text { services provided based on benchmarks with similar competitors and } \\
\text { provide a choice of drugstore make-up or high-end brands. }\end{array}$ \\
\hline 2 & $\begin{array}{l}\text { Price } \\
\text { competitiveness }\end{array}$ & $\begin{array}{l}\text { Make-up artist prices } \\
\text { compete with } \\
\text { one another. }\end{array}$ & $\begin{array}{l}\text { AP Make-up Artist will review the prices presented with competitors by } \\
\text { adjusting the type of make-up desired by the client. }\end{array}$ \\
\hline
\end{tabular}




\begin{tabular}{|c|l|l|l|}
\hline 3 & $\begin{array}{l}\text { Price match } \\
\text { with product } \\
\text { quality }\end{array}$ & $\begin{array}{l}\text { The price of the make-up } \\
\text { artist is in accordance } \\
\text { with the quality of the } \\
\text { product used. }\end{array}$ & $\begin{array}{l}\text { AP Make-up Artist will provide several choices of make-up service } \\
\text { prices that are in accordance with the quality of the product used to } \\
\text { differentiate between drugstore and high-end brand products. }\end{array}$ \\
\hline 4 & $\begin{array}{l}\text { Price match } \\
\text { with benefits }\end{array}$ & $\begin{array}{l}\text { Make-up artist prices } \\
\text { according to the benefits } \\
\text { received. }\end{array}$ & $\begin{array}{l}\text { AP Make-up Artist will provide several choices of make-up service } \\
\text { prices according to the quality of the product used with different events } \\
\text { such as graduation make-up, parties, other photoshoots. }\end{array}$ \\
\hline
\end{tabular}

\section{References}

Ananingsih, T., Hasiholan, L. B., \& Wahyono, E. H. (2018). Pengaruh kualitas produk, promosi, harga dan saluran distribusi terhadap keputusan pembelian produk johnson and johnson Indonesia. Journal of Management, 4(4), $1-10$.

Ariescy, R. R., Amriel, E. E. Y., \& Anindita, R. (2019). Pengaruh iklan hijau dan kesadaran lingkungan terhdap minat beli dan keputusan pembelian air mineral merek Ades di Kabupaten Jember. Jurnal MEBIS (Manajemen Dan Bisnis), 4(2), 142-149. https://doi.org/10.33005/mebis.v4i2.64

Casaló, L. V., Flavián, C., \& Ibáñez-Sánchez, S. (2021). Be creative, my friend! Engaging users on Instagram by promoting positive emotions. Journal of Business Research, 130, 416-425. https://doi.org/10.1016/j.jbusres.2020.02.014

Duane, D., \& Cosenza, R. M. (1996). Business research for decisión making. USA: Wadsworth.

Fildzah, A. N., \& Mayangsari, I. D. (2018). Analisis strategi promosi pada UMKM social enterprise (Studi kasus Pascorner Cafe and Gallery). Jurnal Komunikasi, 12(2), 101-112. https://doi.org/10.20885/komunikasi.vol12.iss2.art1

Health Science Authority. (2020). Cosmetics product. http://www.hsa.gov.sg/cosmetic-products/

Jaya, U. A., \& Sriningsih, W. (2018). Pengaruh lifestyle dan price terhadap buying intention produk smartphone Samsung pada pelajar di Kota Sukabumi. Cakrawala Repositori IMWI, 1(2), 15-27.

Kotler, P., \& Amstrong, G. (2012). Prinsip-prinsip pemasaran. Jakarta: Erlangga.

Kotler, P., \& Keller, K. L. (2016). A framework for marketing management. Global Edition, Pearson Education.

Kusumawati, R. D., Oswari, T., Utomo, R. B., \& Kumar, V. (2014). The influence of 7P's of marketing mix on buying intention of music product in Indonesia. Procedia Engineering, 97, 1765-1771. https://doi.org/10.1016/j.proeng.2014.12.328

Maulana, A., \& Mulyana, M. (2020). Analisis pengaruh public relation dan sales promotion terhadap minat beli pada produk Starbucks di Kota Bogor. Jurnal Ilmiah Manajemen Kesatuan, 8(2), 47-62. https://doi.org/10.37641/jimkes.v8i2.327

Priyanto, D. (2014). SPSS 22 pengolahan data terpraktis. Yogyakarta: Andi Offset.

Priyatno, D. (2014). Mandiri belajar dnalisis Data dengan SPSS. Yogyakarta: Mediakom.

Saragih, B. (2012). Pembangunan sistem agribisnis di Indonesia dan peranan public relations. SOCA: Jurnal Sosial Ekonomi Pertanian, 2615-6628. https://ojs.unud.ac.id/index.php/soca/article/view/4022

Schiffman, L. G., \& Kanuk, L. L. (2018). Perilaku konsumen. Jakarta: Indeks.

Septiani, K. A., Prabawani, B., \& Widayanto, W. (2016). Aktivitas Corporate Social Responsibility (CSR) dan publisitas media: Dampaknya terhadap citra perusahaan dan minat beli (Studi Kasus: konsumen Aqua kelas menengah ke atas di Kota Semarang). Jurnal Ilmu Administrasi Bisnis, 5(1), 58-69.

Sugiyono. (2017). Metode penelitian kuantitatif. Yogyakarta: Alfabeta.

Syaiful, I. A., \& Sari, A. V. K. (2017). Faktor-faktor yang memengaruhi perilaku konsumen dalam bertransaksi di media sosial. Psikohumaniora: Jurnal Penelitian Psikologi, 1(1), 95-112.

Tantono, A. A. (2018). Pengaruh promotion Mix terhadap minat beli konsumen strap. PERFORMA: Jurnal Manajemen Dan Start-Up Bisnis, 2(6), 815-824.

Tristantin, V. V., \& Suwandi, Y. T. (2013). Pengaruh promotion Mix terhadap minat beli konsumen di Family Fun 
Karaoke Keluarga. Jurnal Hospitality Dan Manajemen Jasa, 1(2), 419-429.

Wut, T. M., \& Ng, A. W. (2015). World conference on technology, innovation and entrepreneurship CSR practice and sustainable business performance: Evidence from the global financial centre of China. Procedia - Social and Behavioral Sciences, 195, 133-141. https://doi.org/10.1016/j.sbspro.2015.06.421 